\title{
Improved Slags for ESR Processing of High-Carbon Chromium Bearing Steel
}

\author{
Yang ZHANG ${ }^{1,2) *}$ Weiqing $\mathrm{CHEN}^{1}{ }^{1)}$ Yindong YANG $^{2)}$ and Alex MCLEAN ${ }^{2)}$ \\ 1) State Key Laboratory of Advanced Metallurgy, University of Science and Technology Beijing, Beijing, 100083 China. \\ 2) Department of Materials Science and Engineering, University of Toronto, 184 College Street, Toronto, Ontario M5S 3E4 \\ Canada.
}

(Received on September 13, 2016; accepted on November 1, 2016; J-STAGE Advance published date: December 27, 2016)

\begin{abstract}
Freckles severely affect the quality of high-carbon chromium bearing steel ingots produced by electroslag remelting (ESR). With conventional slags, reducing the melt rate of the electrode can prevent freckle formation, but severe surface defects can still occur. In order to design an appropriate slag for control of segregation and also improve the surface quality of the ingots, the melting temperature, heat transfer properties, and viscosity of several synthetic slags based on the system $\mathrm{CaF}_{2}-\mathrm{CaO}-\mathrm{Al}_{2} \mathrm{O}_{3}-\mathrm{MgO}$ were evaluated. As a consequence of the laboratory investigation, a slag with $50 \% \mathrm{CaF}_{2}$ and a $\mathrm{CaO} / \mathrm{Al}_{2} \mathrm{O}_{3}$ ratio of 1.5, was selected as a candidate for validation on ESR production facilities based on the following package of attractive properties: low melting temperature, low break temperature, low viscosity and high thermal conductivity. Following evaluation of the selected slag formulation on full-scale plant trials, HSLA steel ingots were produced that were free from freckles and exhibited good surface quality.
\end{abstract}

KEY WORDS: electroslag remelting; heat transfer; viscosity; freckles; surface quality.

\section{Introduction}

Due to their excellent properties of fatigue resistance, high hardness and strength, high-carbon chromium bearing steels are widely used under severe conditions where high compression and a large impact load are repeatedly applied over a long period. ${ }^{1,2)}$ Electroslag remelting (ESR) is an important secondary refining process that involves directional solidification in order to control the cast structure, improve cleanness, and reduce defects. The deep $\mathrm{V}$-shaped pool profile with a long mushy zone produces a slow cooling rate and a coarse dendritic structure, which can substantially increase compositional inhomogeneities at the macro level, and lead to the formation of so-called freckle defects. Freckles are channel-like macrosegregation defects that appear as long stringer structures which are rich in some elements that segregate positively, and depleted in some elements that segregate inversely. Freckles have a deleterious effect on mechanical properties and ingots containing these defects must be scrapped because they cannot be removed by any subsequent forging or heat treatment. ${ }^{3-6)}$

Freckle formation is attributed to complex interactions involving solute segregation, thermal variations, dendrite morphology, and processing conditions, all of which influence fluid flow behaviour within the mushy zone. The probability of freckle formation during electro-slag remelting is mainly dependent on the following factors: alloy com-

\footnotetext{
* Corresponding author: E-mail: bestzhangyang1989@gmail.com DOI: http://dx.doi.org/10.2355/isijinternational.ISIJINT-2016-546
}

position, electrode melt rate, horizontal heat transfer, and process parameters such as voltage, current, cooling rate, and casting size. ${ }^{7,8)}$

In ESR process, the viscous flow properties of slag plays a critical role with respect to surface quality of the ingot, and the horizontal heat transfer between ingot and mould is controlled by the solidified slag skin, ${ }^{9,10)}$ and. Inappropriate heat transfer through the slag skin generally results in a deep molten metal pool and severe segregation. Improving the horizontal heat transfer is an important way to control the formation of freckles. As the horizontal heat extraction rate is increased, the cooling rate of the ingot is increased and the local solidification time is decreased. This results in a shallower mushy zone, less intensive interdendritic fluid flow, and finer dendrite arm spacing. In the ESR process, the most important factor controlling the heat transfer is the slag skin thickness. ${ }^{11,12)}$ Generally, slag skin thickness depends on the viscous flow properties of the molten slag at high temperature, which can be characterized in terms of the slag break temperature $T_{B R}$, the temperature below which liquid lubrication starts to break down. The break temperature of the slag also influences the thickness of the liquid slag layer and therefore affects the surface quality of the ingot. ${ }^{10,13,14)}$ Thus it is essential that ESR slags possess proper heat transfer and viscous flow properties in order to meet the requirements for segregation control and surface quality of the ingot during the solidification process.

With the aim of achieving good internal structure as well as good surface quality in the cast ingots, the effects of $\mathrm{CaF}_{2}$ content and $\mathrm{CaO} / \mathrm{Al}_{2} \mathrm{O}_{3}$ ratio on slag performance 
were examined. The thermal characteristics and viscosity behavior of ESR type $\mathrm{CaF}_{2}-\mathrm{CaO}-\mathrm{Al}_{2} \mathrm{O}_{3}-\mathrm{MgO}$ slags were investigated using a heat transfer simulator and a rotating cylinder technique. In addition, plant trials were conducted in order to study the effects of slag composition on their behavior in the mold during the ESR process.

\section{Formation of Defects during Electroslag Remelting of HSLA Steel}

High-carbon chromium bearing steels are segregation sensitive alloys and freckles are frequently observed in the ESR ingots. Figure 1 shows macrographs of slices along the length of a 720-mm-diameter GCr15SiMn steel ingot. A pronounced change in the ingot macrostructure can be seen. It can be observed that freckles were generated in the mid-radius region of the ingot but not in the center. Freckles are apparent as parallel straight lines with basically the same orientation, and at an almost constant angle to the primary dendrites. Within a given region, there is only one freckle channel. The orientation of freckle channels are close to vertical but are slightly inclined from the inside to the outside of the ingot.

The most commonly used operating parameter for prevention of freckles is the melt rate. A low melt rate results in a high cooling rate, a shorter mushy zone, and finer dendrite arm spacing in the ingot. However, a low melt rate will also result in an increase in the thickness of the slag skin, and this can have adverse effects on viscous flow properties of slag and consequently on the surface quality of the ingot.

A 720-mm-diameter ingot (Fig. 3) of GCr15SiMn was produced on an industrial-scale ESR furnace. The nominal composition of the steel is shown in Table 1. In order to prevent the formation of freckles, the average melt rate of the electrode was reduced from $9.7 \mathrm{~kg} / \mathrm{min}$ to $7.2 \mathrm{~kg} / \mathrm{min}$. By macro etching longitudinal and transverse sections it was confirmed that the cast structure did not contain freckle defects (Fig. 2). However, it can be observed from Fig. 3

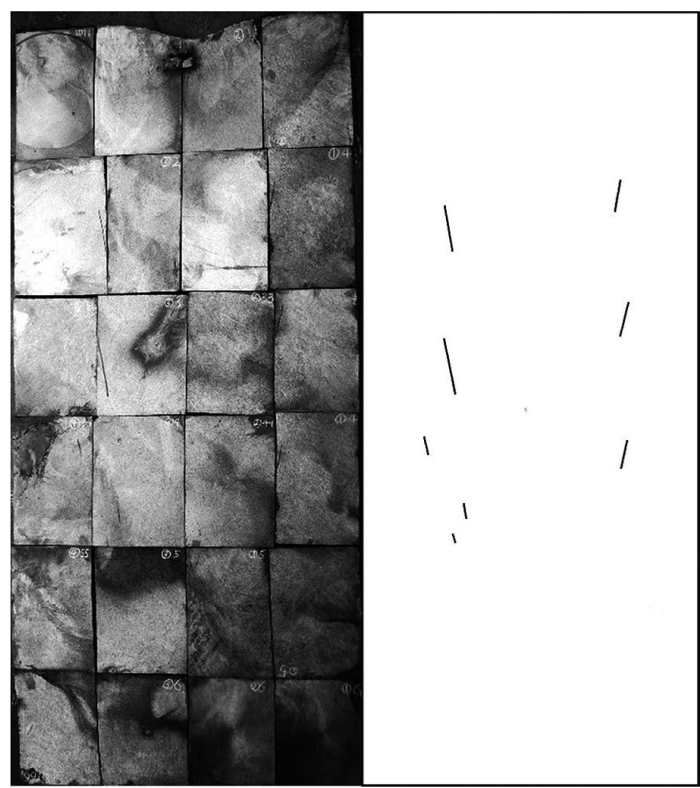

Fig. 1. Longitudinal macrostructures of ingot with average melt rate $9.7 \mathrm{~kg} / \mathrm{min}$.
Table 1. Chemical composition of GCr15SiMn alloy steel, $\operatorname{mass} \%$.

\begin{tabular}{cccccccccc}
\hline $\mathrm{C}$ & $\mathrm{Si}$ & $\mathrm{Mn}$ & $\mathrm{P}$ & $\mathrm{S}$ & $\mathrm{Cr}$ & $\mathrm{Mo}$ & $\mathrm{Ni}$ & $\mathrm{Al}$ & $\mathrm{Ti}$ \\
\hline 1.00 & 0.56 & 1.06 & 0.018 & 0.001 & 1.53 & 0.06 & 0.04 & 0.014 & 0.012
\end{tabular}

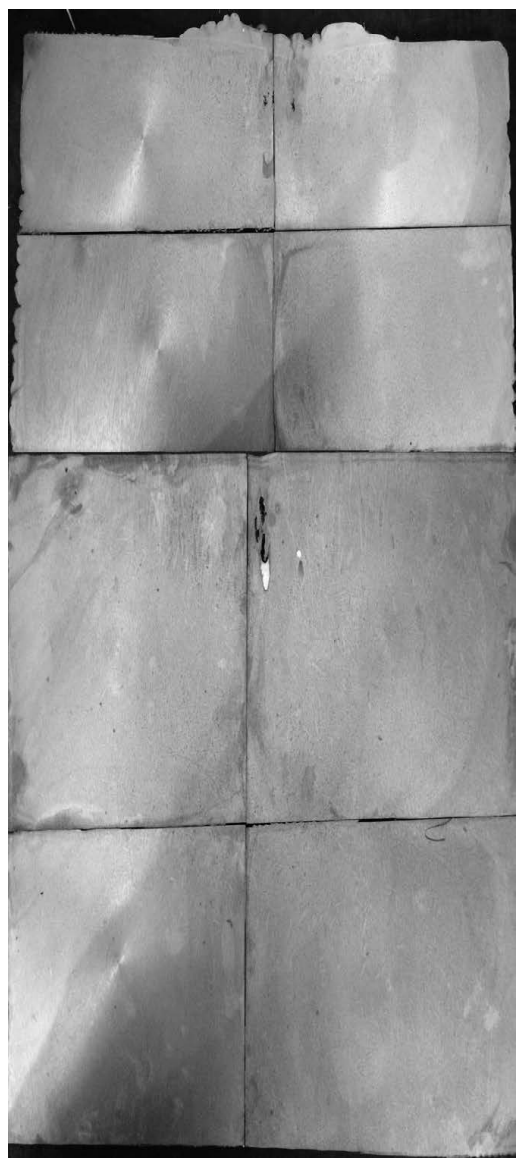

Fig. 2. Longitudinal macrostructures of ingot with average melt rate $7.2 \mathrm{~kg} / \mathrm{min}$.

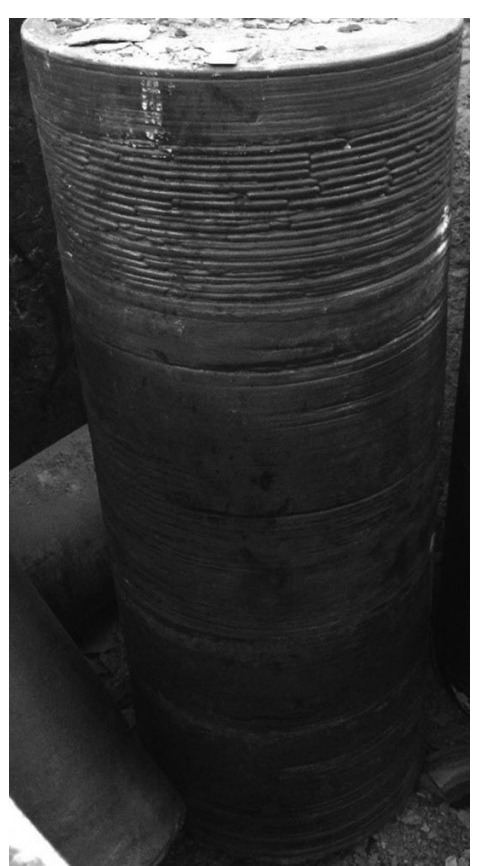

Fig. 3. An ESR ingot with poor surface quality, produced using a conventional ESR slag. 
that the surface quality of the ingot is very poor.

Because of the high strength and crack sensitivity of this HSLA steel, the deep, wavy surface defects cannot be removed by grinding. It was concluded therefore, that a new slag was needed that would have appropriate heat transfer and viscosity properties in order to meet the requirements for freckle prevention and good surface quality during the production of HSLA steel by the electro-slag remelting process.

\section{Experimental Aspects}

\subsection{Preparation of Synthetic Slags}

It is evident from consideration of the $\mathrm{CaF}_{2}-\mathrm{CaO}-\mathrm{Al}_{2} \mathrm{O}_{3}$ ternary phase diagram together with viscosity data that the $\mathrm{CaF}_{2}$ content and $\mathrm{CaO} / \mathrm{Al}_{2} \mathrm{O}_{3}$ mass ratio have significant effects on the melting temperature and viscosity behavior of molten slags. With this in mind, 7 slags with varying $\mathrm{CaF}_{2}$ content and $\mathrm{CaO} / \mathrm{Al}_{2} \mathrm{O}_{3}$ ratios were designed for the purpose of conducting comparative experiments. The chemical compositions of the slags as determined by XRF analysis, are listed in Table 3. The original slag used in production operations is shown as A0. The experimental slags, synthesized using reagent grade chemicals $\mathrm{CaF}_{2}, \mathrm{Al}_{2} \mathrm{O}_{3}, \mathrm{CaO}$ and $\mathrm{MgO}$, were pre-melted in a graphite crucible at $1450^{\circ} \mathrm{C}$ for $1 \mathrm{~h}$ with $\mathrm{Ar}$ as a protective gas and then water-quenched. Quenched slags were dried at $120^{\circ} \mathrm{C}$ for $4 \mathrm{~h}$, crushed into powder with a particle size less than $75 \mu \mathrm{m}$ and stored for use in subsequent experiments.

\subsection{Melting Temperature Tests}

Slag melting experiments were carried out using a high temperature specimen deformation method. A diagram of the test system is shown in Fig. 4. To evaluate the melt-

Table 2. ESR process parameters.

\begin{tabular}{ccccc}
\hline Slag composition & $\mathrm{CaF}_{2}$ & $\mathrm{Al}_{2} \mathrm{O}_{3}$ & $\mathrm{CaO}$ & $\mathrm{MgO}$ \\
(mass pct) & 55 & 30 & 10 & 5 \\
Slag amount & \multicolumn{4}{c}{$150 \mathrm{~kg}$} \\
Furnace voltage & \multicolumn{2}{c}{$75-80 \mathrm{~V}$} \\
Current & $15000 \pm 2000 \mathrm{~A}$ \\
\hline
\end{tabular}

Table 3. Slag compositions before and after pre-melting (mass pct).

\begin{tabular}{ccccccccccc}
\hline \multirow{2}{*}{$\begin{array}{c}\text { Sample } \\
\text { No. }\end{array}$} & $\mathrm{Al}_{2} \mathrm{O}_{3}$ & \multicolumn{3}{c}{ Before Pre-melting } & \multicolumn{4}{c}{ After Pre-melting } \\
\cline { 3 - 10 } & $\mathrm{CaF}_{2}$ & $\mathrm{Al}_{2} \mathrm{O}_{3}$ & $\mathrm{CaO}$ & $\mathrm{MgO}$ & $\mathrm{CaF}_{2}$ & $\mathrm{Al}_{2} \mathrm{O}_{3}$ & $\mathrm{CaO}$ & $\mathrm{MgO}$ \\
\hline $\mathrm{A} 0$ & 0.3 & 55 & 30 & 10 & 5 & 52.19 & 30.58 & 11.49 & 5.74 \\
$\mathrm{~A} 1$ & 1 & 45 & 25 & 25 & 5 & 42.11 & 24.78 & 27.41 & 5.7 \\
$\mathrm{~A} 2$ & 1 & 50 & 22.5 & 22.5 & 5 & 47.5 & 22.52 & 24.3 & 5.68 \\
$\mathrm{~A} 3$ & 1 & 55 & 20 & 20 & 5 & 51.69 & 20.47 & 22.4 & 5.44 \\
$\mathrm{~B} 1$ & 0.5 & 50 & 30 & 15 & 5 & 47.3 & 29.9 & 17.08 & 5.72 \\
$\mathrm{~B} 2$ & 1.5 & 50 & 18 & 27 & 5 & 47.31 & 17.74 & 29.95 & 5 \\
$\mathrm{~B} 3$ & 2 & 50 & 15 & 30 & 5 & 46.97 & 14.57 & 33.06 & 5.4 \\
$\mathrm{~B} 4$ & 3 & 50 & 11.25 & 33.75 & 5 & 47.1 & 11.25 & 36.59 & 5.06 \\
\hline
\end{tabular}

ing behaviour, the slag powders were compressed into cylindrical samples $3 \mathrm{~mm}$ diameter and $3 \mathrm{~mm}$ high. For each test, the slag sample was placed at the centre of a corundum substrate which was then located within the hot zone of a molybdenum wire furnace, under a $0.1 \mathrm{MPa}$ argon atmosphere of $99.99 \%$ purity. The furnace was heated at $10^{\circ} \mathrm{C} / \mathrm{min}$ up to the slag melting temperature, which is defined as the temperature at which the cylindrical specimen attained a hemispherical shape.

\subsection{Heat Transfer Experiments}

Heat transfer experiments were carried out using a vertical tube furnace. A schematic diagram of the test facility is shown in Fig. 5. The equipment consisted of the heating unit, a pure iron crucible, a water-cooled copper column, three thermocouples and a graphite gasket. The cast slab and water-cooled copper mould associated with the ESR production system were replicated by the iron crucible and the water-cooled copper column respectively. The gasket was used to adjust the distance between the crucible and the copper column. The crucible had an outer diameter of $70 \mathrm{~mm}$, an inner diameter of $60 \mathrm{~mm}$, an overall height of $25 \mathrm{~mm}$ and a bottom thickness of $5 \mathrm{~mm}$. The flux film

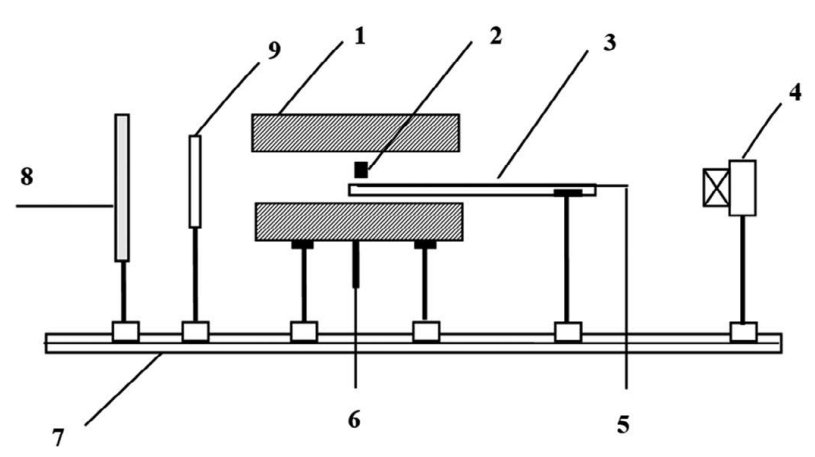

Fig. 4. Test facility for determination of slag melting behaviour: 1-molybdenum wire furnace, 2-slag sample, 3-corundum holder, 4-light source, 5-WRR 30/6 thermocouple (type B), 6-temperature control system, 7-track, 8-screen, 9-filter (constitute by two parallel convex lens).

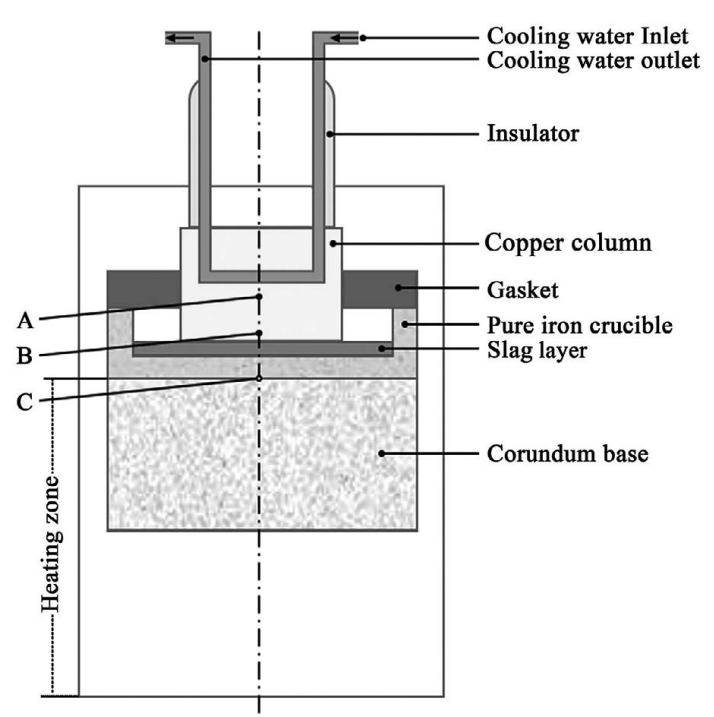

Fig. 5. Schematic diagram of the test facility for heat transfer experiments. 
was kept at a constant thickness of $2 \mathrm{~mm}$. Two Ni-Cr/ Ni-Si thermocouples (type K) A and B, and a WRe 5/26 thermocouple $\mathrm{C}$ were employed to measure the temperature at different locations within the experimental facility. The distances from thermocouple A and thermocouple B to the base of the copper column were $10 \mathrm{~mm}$ and $2 \mathrm{~mm}$ respectively. Thermocouple $\mathrm{C}$ was in direct contact with the base of the iron crucible.

The vertical furnace contained a carbon tube heating element and argon (99.99\% purity) was used as a protective gas. The iron crucible was placed in the upper region of the constant temperature zone to minimize the effect of radiation heat transfer. The cooling water tube for the copper column was wrapped with heat insulating material.

At the beginning of an experiment, when the temperature at location $\mathrm{C}$ was $1623 \mathrm{~K}\left(1350^{\circ} \mathrm{C}\right), 30 \mathrm{~g}$ of pre-melted slag was added to the iron crucible. After about $30 \mathrm{~min}$, when the slag had melted and the temperature at location $\mathrm{C}$ had again stabilized at $1623 \mathrm{~K}\left(1350^{\circ} \mathrm{C}\right)$, the copper column with a cooling-water flow-rate of $120 \mathrm{~L} / \mathrm{h}$ was inserted into the crucible and the temperatures at locations A, B and C were continuously recorded, Fig. 6. Under these conditions, heat transfer across the flux film to the base of the water-cooled copper column can be viewed in terms of one-dimensional steady-state heat transfer.

Based on the temperature measurements at locations A, B and $\mathrm{C}$, and the given system parameters, heat transfer factors can be calculated using the following equations:

Total heat flux $q\left(\mathrm{Wm}^{-2}\right)$ across the flux film can be calculated by Eq. (1).

$$
q=\lambda_{\mathrm{Cu}}\left(T_{\mathrm{B}}-T_{\mathrm{A}}\right) / d_{\mathrm{AB}}
$$

The base temperature $\mathrm{T}_{\mathrm{Cu} \text {-base }}(\mathrm{K})$ of the water-cooled copper column can be calculated by Eq. (2).

$$
T_{\text {Cu-base }}=T_{\mathrm{A}}+q d_{\mathrm{A}} / \lambda_{\mathrm{Cu}}
$$

Interfacial temperature $\mathrm{T}_{\mathrm{Fe}-\mathrm{S}}(\mathrm{K})$ between the slag layer and the iron crucible can be calculated by Eq. (3).

$$
T_{\mathrm{Fe}-\mathrm{S}}=T_{\mathrm{C}}-q d_{\mathrm{C}} / \lambda_{\mathrm{Fe}}
$$

The thermal conductivity of the flux $\lambda_{\mathrm{T}}\left(\mathrm{Wm}^{-1} \mathrm{~K}^{-1}\right)$ can be calculated by Eq. (4).

$$
\lambda_{\mathrm{T}}=q d_{\mathrm{S}} /\left(T_{\mathrm{Fe}-\mathrm{S}}-T_{\text {Cu-base }}\right)
$$

The thermal resistance of the flux $R_{\mathrm{T}}\left(\mathrm{m}^{2} \mathrm{KW}^{-1}\right)$ can be calculated by Eq. (5).

$$
\begin{aligned}
R_{\mathrm{T}} & =\left(T_{\mathrm{Fe}-\mathrm{S}}-T_{\text {Cu-base }}\right) / q \\
& =\left[\left(T_{\mathrm{C}}-T_{\mathrm{A}}\right) d_{\mathrm{AB}}\right]\left[\left(T_{\mathrm{B}}-T_{\mathrm{A}}\right) \lambda_{\mathrm{Cu}}\right]-\left(d_{\mathrm{C}} / \lambda_{\mathrm{Fe}}+d_{\mathrm{A}} / \lambda_{\mathrm{Cu}}\right)
\end{aligned}
$$

Where $\lambda_{\mathrm{Cu}}, \lambda_{\mathrm{Fe}}$ are the thermal conductivities of the copper column and the iron crucible respectively. According to the measured results, the temperature of the water-cooled copper column was less than $373 \mathrm{~K}\left(100^{\circ} \mathrm{C}\right)$ and the temperature of the iron crucible was about $1473 \mathrm{~K}\left(1200^{\circ} \mathrm{C}\right)$. Values of $\lambda_{\mathrm{Cu}}$ at $373 \mathrm{~K}\left(100^{\circ} \mathrm{C}\right)$ and $\lambda_{\mathrm{Fe}}$ at $1473 \mathrm{~K}\left(1200^{\circ} \mathrm{C}\right)$ were found to be $393 \mathrm{Wm}^{-1} \mathrm{~K}^{-1}$ and $31.6 \mathrm{Wm}^{-1} \mathrm{~K}^{-1}$, respectively. ${ }^{15)}$ It is therefore assumed that $\lambda_{\mathrm{Cu}}$ and $\lambda_{\mathrm{Fe}}$ can be considered as constants for the range of temperatures involved in the current experiments.

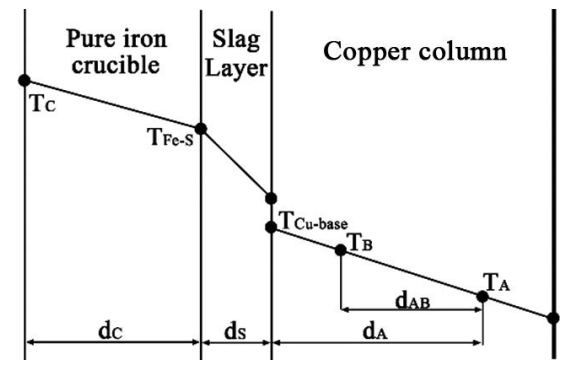

Fig. 6. Temperature distribution during heat transfer experiments.

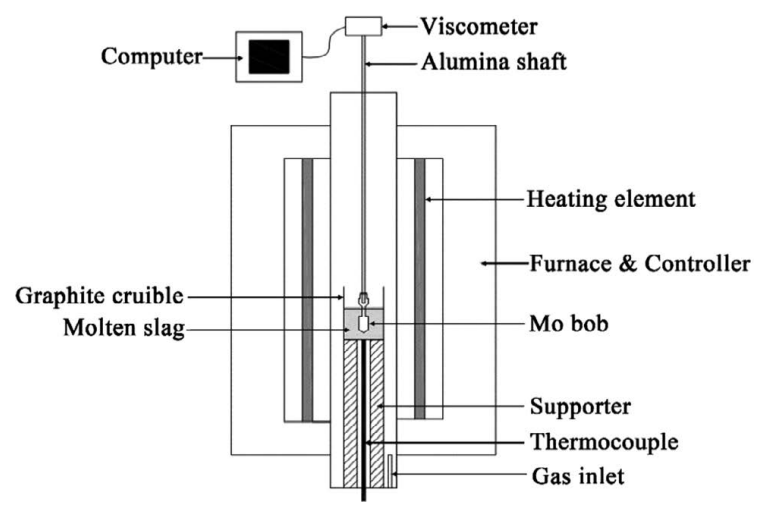

Fig. 7. Schematic diagram of the equipment for viscosity measurements.

\subsection{Viscosity Measurements}

A schematic diagram of the equipment used for viscosity measurements based on the rotating cylinder method is shown in Fig. 7. The furnace was equipped with $\mathrm{MoSi}_{2}$ heating elements. The rotating viscometer was connected with a computer to continuously record the value of the torque generated by the rotation of the Mo spindle. Standard oil samples with a viscosity of $\eta=4.306 \times 10^{-11} \exp (6.993 / \mathrm{T})$ were used to calibrate the viscometer. The temperature was measured using an S-type (Pt/Pt-10 pct Rh) thermocouple contained in an alumina sheath and placed in contact with the base of the graphite crucible. The temperatures for the viscosity measurements were in the range 1473 to $1773 \mathrm{~K}$ (1 200 to $\left.1500^{\circ} \mathrm{C}\right)$.

The experimental procedure was initiated by placing 130 $\mathrm{g}$ of premelted slag in the graphite crucible (height- $80 \mathrm{~mm}$, inner diameter-40 mm). The crucible and contents were positioned inside the furnace and heated under an $\mathrm{Ar}$ atmosphere to $1773 \mathrm{~K}\left(1500^{\circ} \mathrm{C}\right)$ at a rate of $15^{\circ} \mathrm{C} / \mathrm{min}$. When molten, the depth of the slag layer is about $40 \mathrm{~mm}$. After holding at $1773 \mathrm{~K}\left(1500^{\circ} \mathrm{C}\right)$ for $30 \mathrm{~min}$, the spindle is lowered into the slag and rotated at a speed of $200 \mathrm{rpm}$. All of the viscosity measurements were performed during cooling from $1773 \mathrm{~K}\left(1500^{\circ} \mathrm{C}\right)$ at a rate of $5^{\circ} \mathrm{C} / \mathrm{min}$.

\section{Results and Discussion}

\subsection{Melting Temperature}

The melting temperature of slag was measured using a high temperature microscope. The melting temperature of A0 slag is $1689 \mathrm{~K}\left(1416^{\circ} \mathrm{C}\right)$. The results for the synthetic slags are shown in Fig. 8. From Fig. 8(a) it can be seen that with a $\mathrm{CaO} / \mathrm{Al}_{2} \mathrm{O}_{3}$ ratio $=1$, the melting temperature of the 

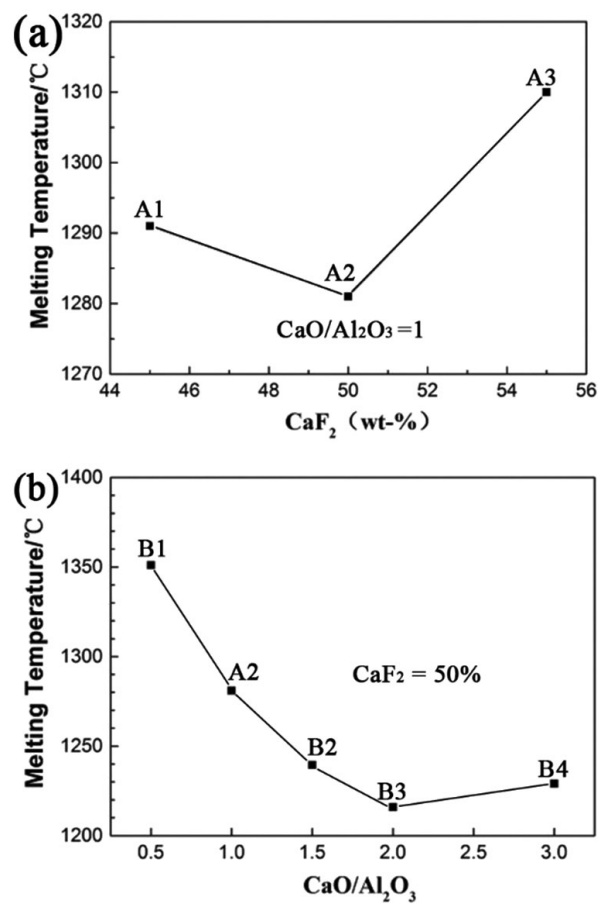

Fig. 8. Effect of (a) $\mathrm{CaF}_{2}$ content and (b) $\mathrm{CaO} / \mathrm{Al}_{2} \mathrm{O}_{3}$ ratio on the melting temperature of slags.

slags has a minimum value at $50 \mathrm{wt} \% \mathrm{CaF}_{2}$. The results in Fig. 8(b) show that there is an almost linear relationship between the melting temperature and the $\mathrm{CaO} / \mathrm{Al}_{2} \mathrm{O}_{3}$ ratio. Increase in the $\mathrm{CaO} / \mathrm{Al}_{2} \mathrm{O}_{3}$ ratio, due to a decrease in $\mathrm{Al}_{2} \mathrm{O}_{3}$ and/or an increase in $\mathrm{CaO}$, leads to a significant decrease in the melting temperature which reaches a minimum value at a $\mathrm{CaO} / \mathrm{Al}_{2} \mathrm{O}_{3}$ ratio of 2.0. This behavior is related to the precipitation of solid phases with high melting points in slags with high $\mathrm{Al}_{2} \mathrm{O}_{3}$ content.

\subsection{Heat Transfer}

The measured heat flux density as a function of time is shown in Fig. 9. It can be seen that the change of heat flux density with time can be divided into three stages: (I) the ascent stage from 0 to $50 \mathrm{~s}$, (II) the descent stage from 50 to $300 \mathrm{~s}$, and (III) the stable stage which js achieved after about $300 \mathrm{~s}$. The ascent stage reflects the initial increase in heat flux density between the copper column and the molten slag. The heat flux density reaches a maximum value and then decreases. This descent stage reflects the formation and crystallization of a solid slag layer which causes the heat flux density to decrease. Eventually, after about $300 \mathrm{~s}$ when the solid slag layer has formed completely, the heat flux tends to a stable value.

The values in Fig. 9 for thermal conductivity and thermal resistance are the average values that were calculated from the results obtained during the stable stage of the heat flux measurements as shown in Fig. 9. The effects of $\mathrm{CaF}_{2}$ content on the thermal conductivity and thermal resistance of different slags are shown in Fig. 10(a), these results were calculated using the equations mentioned previously. It can be seen that thermal conductivity increases significantly with increasing $\mathrm{CaF}_{2}$ content. This result is consistent with work by Dong et al. ${ }^{16)}$ who found a similar tendency. The increase in $\mathrm{CaF}_{2}$ content result in the depolymerisation of

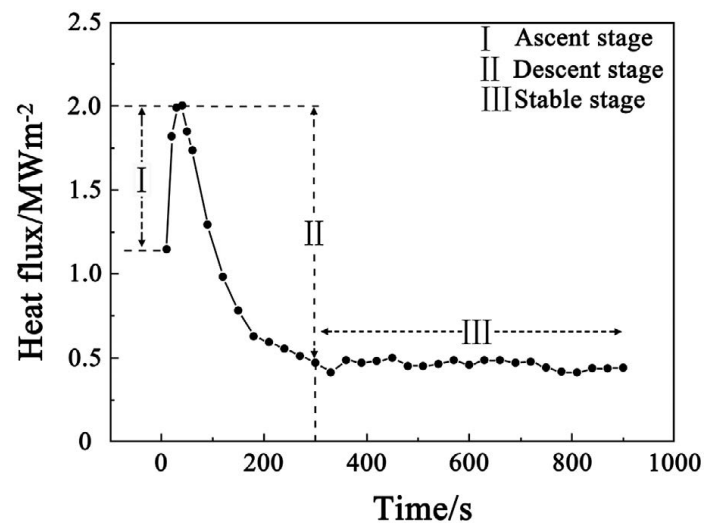

Fig. 9. Change in heat flux with the formation of a solid slag layer.
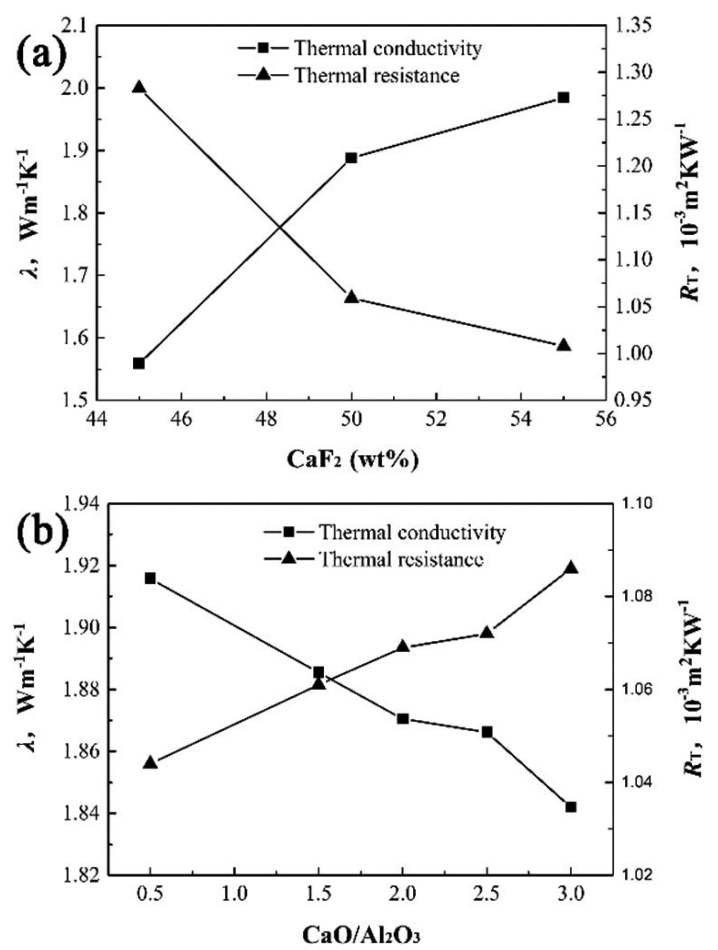

Fig. 10. Effect of (a) $\mathrm{CaF}_{2}$ content and (b) $\mathrm{CaO} / \mathrm{Al}_{2} \mathrm{O}_{3}$ ratio on thermal conductivity and thermal.

the aluminate melts, according to the work of Park et al., ${ }^{17)}$ for slag with less than $24\left(\mathrm{~mol}_{\%}\right) \mathrm{CaF}_{2}$, the $\mathrm{F}^{-}$ions from $\mathrm{CaF}_{2}$ react with $\left[\mathrm{AlO}_{4}\right]$-tetrahedra as following equation shows.

$$
3\left[\mathrm{AlO}_{4}\right]^{5-}+6 \mathrm{~F}^{-}=\left[\mathrm{AlF}_{6}\right]^{3-}+2\left[\mathrm{AlO}_{6}\right]^{9-}
$$

In this study, all the slag samples with a $\mathrm{CaF}_{2}$ content more than $24(\mathrm{~mol} \%)$. Since the activity of $\mathrm{Al}_{2} \mathrm{O}_{3}$ is significantly low and that of $\mathrm{CaF}_{2}$ is nearly constant, the driving force of the depolymerization reaction given in Eq. (6) would be less than the activation energy. The depolymerization reaction would be inhibited with increasing $\mathrm{CaF}_{2}$ content, the aluminate network within the molten slag would keep relatively high polymerized structures that doesn't in favour of the crystallization of solid particles, thus decrease the viscosity of slags. On the other hand, according to the phase diagram of $\mathrm{CaO}-\mathrm{Al}_{2} \mathrm{O}_{3}-\mathrm{CaF}_{2}$ system, ${ }^{18)}$ on the same $\mathrm{CaO} / \mathrm{Al}_{2} \mathrm{O}_{3}$ ratio condition, the liquidus tempreatures of slags decreases with increasing $\mathrm{CaF}_{2}$ content in composition range of this study. 
Therefore, there are less solid particles would precipitate at the same temperature for slags with higher $\mathrm{CaF}_{2}$ content, which result in higher thermal conductivity.

It also can be found that thermal conductivity decreases and thermal resistance increases with increasing $\mathrm{CaO} /$ $\mathrm{Al}_{2} \mathrm{O}_{3}$ ratio, Fig. 10(b). The increase in $\mathrm{CaO}$ content result in the increase in free oxygen $\left(\mathrm{O}^{2-}\right)$ and depolymerize the complex aluminates and aluminates into a simpler structure, thus lower the thermal conductivity of slags. It is apparent from these results that the influence of $\mathrm{CaF}_{2}$ content on thermal conductivity is much greater than that of the $\mathrm{CaO}$ / $\mathrm{Al}_{2} \mathrm{O}_{3}$ ratio.

\subsection{Viscosity Behaviour}

Figure 11 illustrates the viscosity of slag samples with different $\mathrm{CaO} / \mathrm{Al}_{2} \mathrm{O}_{3}$ ratio as a function of temperature. It can be seen that $\mathrm{CaO} / \mathrm{Al}_{2} \mathrm{O}_{3}$ ratio has a great effect on the viscosity of the slag sample, the viscosity decreases with the increasing $\mathrm{CaO} / \mathrm{Al}_{2} \mathrm{O}_{3}$ ratio. In molten slags containing $\mathrm{Al}_{2} \mathrm{O}_{3}$, the aluminate structure would be composed of predominant $\left[\mathrm{AlO}_{4}\right]$-tetrahedron and minor $\left[\mathrm{AlO}_{6}\right]$-octahedron units. ${ }^{17)}$ The highly polymerized structures of complex aluminates $\left[\mathrm{AlO}_{4}\right]$-tetrahedral groups within the slag melts gradually depolymerize with the increasing $\mathrm{CaO}$ content, the $\mathrm{O}^{2-}$ ions dissociated from $\mathrm{CaO}$ would react with $\left[\mathrm{AlO}_{4}\right]-$ tetrahedra to form $\left[\mathrm{AlO}_{6}\right]$-octahedra, as following equation shows.

$$
\mathrm{n}\left[\mathrm{AlO}_{4}\right]^{5-}+2 \mathrm{nO}^{2-}=\mathrm{n}\left[\mathrm{AlO}_{6}\right]^{9-}
$$

With increase in the $\mathrm{O}^{2-}$ and $\mathrm{Ca}^{2+}$ ions, the depolymerization reactions result in the structure of the molten slag changes to an unstable and depolymerized network. As the $\left[\mathrm{AlO}_{4}\right]$-tetrahedral behaves as the network former, the band weakens and the fraction of simple $\left[\mathrm{AlO}_{6}\right]$-octahedron units increases with increasing $\mathrm{CaO}$ content, therefore the viscosity of the molten slag decreases.

When viscosity measurements are carried out during a cooling cycle, there is a point at which the viscosity increases suddenly and the slag becomes non-Newtonian in behaviour. This is referred to as the break temperature, $T_{B R}$, the temperature below which liquid lubrication starts to break down. The break temperature also represents the point at which the activation energy for the viscous flow

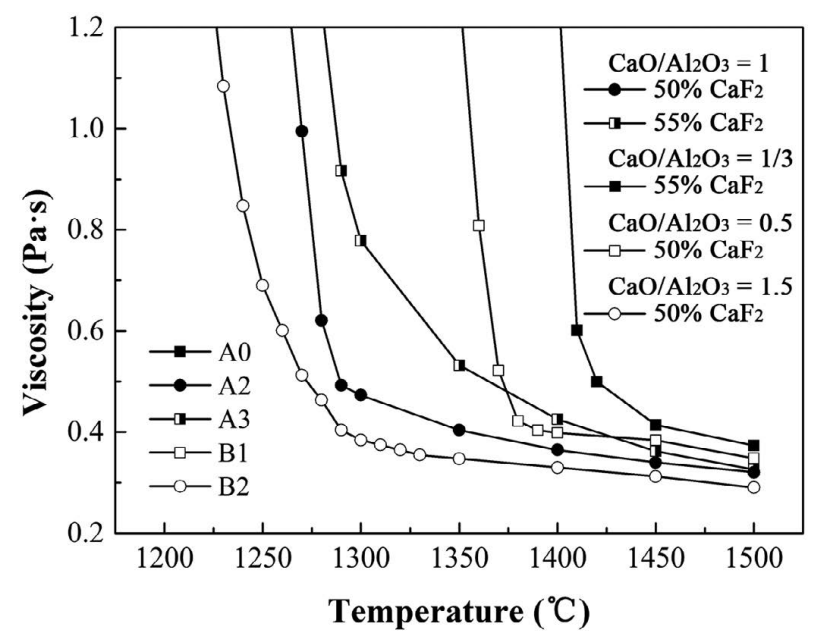

Fig. 11. Viscosities of selected slags as a function of temperature. of slags increases abruptly due to the precipitation of solid phases in the melt.

As mentioned previously, high-carbon chromium bearing steels are segregation sensitive, thus the melting temperature of slags should be $150-250^{\circ} \mathrm{C}$ lower than the melting temperature of the steel $1763 \mathrm{~K}\left(1490^{\circ} \mathrm{C}\right)$. If the melting temperature of slags is too low, this will increase the electrical conductivity of the slags and result in lower slag temperatures, which will eventually contribute to the formation of shrinkage defects. Comparing measured melting temperatures and heat transfer data, slags A2, A3, B1, and $\mathrm{B} 2$ have an appropriate combination of properties and were selected for measurement of viscosity. The results obtained are shown in Fig. 11, it can be observed from this figure that the break temperature of slags increases as the $\mathrm{CaO} / \mathrm{Al}_{2} \mathrm{O}_{3}$ ratio decreases. It is significant that $T_{B R}$ of the original slag A0 is too high. This will result in a thick slag skin and poor surface quality. It is also noteworthy that the activation energy for the viscous flow of slags decreases with decreasing $T_{B R}$, thus the viscous flow properties of the molten slag is improved.

\subsection{Production Plant Trials}

Based on measured results of melting temperature, heat transfer, and viscosity of the slags, slag B2 was selected as the most appropriate for evaluation in full-scale plant trials. Except for the slag composition, all other process parameters were the same as those for the previous plant evaluation described in Section 2. In order to assess the effectiveness of the new slag, freckle formation and surface quality were evaluated. In addition, the average thickness of the slag skin was determined. For this purpose, samples of slag skin were obtained at $30 \mathrm{~cm}$ intervals along the longitudinal direction from the surface of the solidified ingot (Fig. 12), the results for skin thickness shown in Table $\mathbf{4}$ represent the average

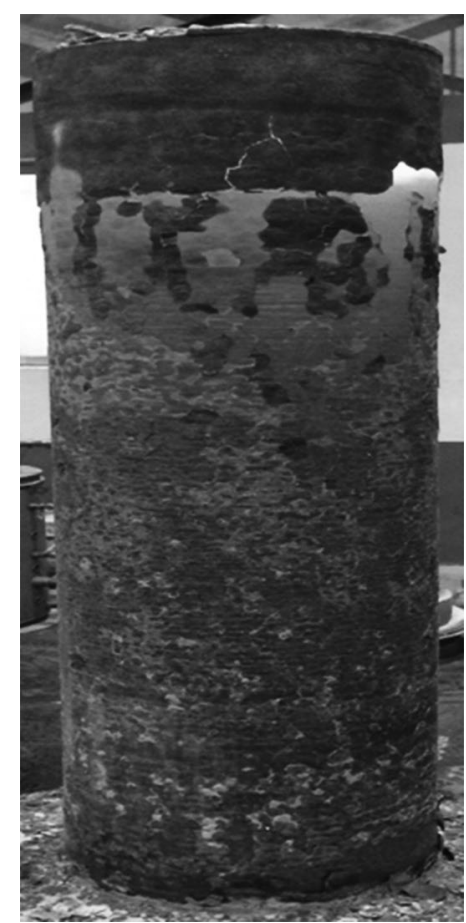

Fig. 12. An ESR ingot of GCr15SiMn steel with good surface quality, produced using the new slag. 
Table 4. Results of plant trials with original (A0) and new (B2) slag formulations.

\begin{tabular}{ccccc}
\hline Slag No. & $\begin{array}{c}\text { Average melt rate } \\
(\mathrm{kg} / \mathrm{min})\end{array}$ & $\begin{array}{c}\text { Thickness of slag } \\
\text { skin }(\mathrm{mm})\end{array}$ & $\begin{array}{c}\text { Surface } \\
\text { defects }\end{array}$ & Freckle \\
\hline A0 & $7.2 \mathrm{~kg} / \mathrm{min}$ & 2.7 & Yes & None \\
B2 & $7.4 \mathrm{~kg} / \mathrm{min}$ & 1.5 & None & None \\
\hline
\end{tabular}

values of all the measurements. It is evident that use of the new slag with a high thermal conductivity and a low break temperature is effective for thinning the slag skin, improving the surface quality of the ingot and preventing freckle formation.

\section{Conclusions}

Laboratory experiments and plant trials were conducted in order to study the effects of $\mathrm{CaF}_{2}$ content and $\mathrm{CaO} / \mathrm{Al}_{2} \mathrm{O}_{3}$ ratio on melting temperature, heat transfer and viscosity properties of ESR slags used for high-carbon chromium bearing steels. The main conclusions can be summarized as follows:

(1) Using a conventional slag for ESR processing, although freckle formation in the ingot can be controlled by a low melt rate, this results in slag skin thickening and generates severe surface defects.

(2) The melting temperature of slags with a $\mathrm{CaO} / \mathrm{Al}_{2} \mathrm{O}_{3}$ ratio of 1.0 reached a minimum value at $50 \mathrm{wt} \% \mathrm{CaF}_{2}$. For slags with $50 \mathrm{wt} \% \mathrm{CaF}_{2}$, the melting temperature decreases as the $\mathrm{CaO} / \mathrm{Al}_{2} \mathrm{O}_{3}$ ratio increases.

(3) Increase in $\mathrm{CaF}_{2}$ content increases the thermal conductivity of the liquid slag. In contrast, increasing the $\mathrm{CaO} /$ $\mathrm{Al}_{2} \mathrm{O}_{3}$ ratio has the opposite effect. However the influence of $\mathrm{CaF}_{2}$ on these slag properties is very much greater than that of the $\mathrm{CaO} / \mathrm{Al}_{2} \mathrm{O}_{3}$ ratio. And viscosity measurements showed that the break temperature of slags increases as the $\mathrm{CaO} / \mathrm{Al}_{2} \mathrm{O}_{3}$ ratio decreases.
(4) Based on the measurement of properties, a slag B2 containing $50 \% \mathrm{CaF}_{2}$ and with a $\mathrm{CaO} / \mathrm{Al}_{2} \mathrm{O}_{3}$ ratio of 1.5 was selected for further evaluation on ESR production facilities. Following plant trials it was confirmed that the B2 slag formulation was effective for thinning the slag skin, improving the surface quality of the ingot and preventing freckle formation.

\section{Acknowledgments}

The financial support by the China Scholarship Council (CSC) is gratefully acknowledged. The financial support provided by the Natural Sciences and Engineering Research Council of Canada (NSERC) for steel-related research at the University of Toronto is also gratefully acknowledged.

\section{REFERENCES}

1) C. Huang, C. L. Zhang, L. Jiang, Y. Yang and Y. Z. Liu: J. Alloy. Compd., 660 (2016), 131.

2) J. Zhao, T. Zhao, C. S. Hou, F. C. Zhang and T. S. Wang: Mater. Des., 86 (2015), 215

3) P. Auburtin, T. Wang, S. Cockcroft and A. Mitchell: Metall. Mater. Trans. B, 31 (2000), 801.

4) D. Ma, Q. Wu and A. Buehrig-Polaczek: Metall. Mater. Trans. B, 43 (2012), 344.

5) J. Valdés, P. King and X. Liu: Metall. Mater. Trans. A, 41 (2010), 2408.

6) L. Yuan and P. D. Lee: Acta Mater., 60 (2012), 4917.

7) Z. Long, X. Liu, W. Yang, K. M. Chang and E. Barbero: Mater. Sci. Eng. A, 386 (2004), 254.

8) W. H. Yang, J. J. de Barbadillo, K. Morita, T. Suzuki, W. Chen and K. M. Chang: JOM, 56 (2004), 56.

9) J. W. Cho, T. Emi, H. Shibata and M. Suzuki: ISIJ Int., 38 (1998), 834.

10) K. C. Mills, A. B. Fox, Z. Li and R. P. Thackray: Ironmaking Steelmaking, 32 (2005), 26.

11) K. O. Yu, J. A. Domingue, G. E. Maurer and H. D. Flanders: JOM, 38 (1986), 46.

12) A. Mitchell: Mater. Sci. Eng. A, 413 (2005), 10.

13) A. Mitchell and S. Joshi: Mater. Trans., 4 (1973), 631.

14) R. C. Behera and U. K. Mohanty: ISIJ Int., 41 (2001), 834

15) Y. S. Shen, B. W. Li and M. L. Wu: Basic Principle of Metallurgical Transfer, Metallurgical Industry Press, Beijing, (2006), 455.

16) Y. Dong, Z. Jiang, Y. Cao, D. Hou, L. Liang and J. Duan: ISIJ Int., 55 (2015), 904.

17) J. H. Park, D. J. Min and H. S. Song: ISIJ Int., 42 (2002), 38.

18) Slag Atlas, 2nd ed., ed. by Verein Deutscher Eisenhüttenleute, Verlag Stahleisen GmbH, Düsseldorf, (1995), 191. 